\title{
Estimation of phenotypic divergence in a collection of Cucumis melo from Kerala State, Southern India
}

\author{
Sunita Premnath Koli, Hosakatte Niranjana Murthy* \\ Department of Botany, Karnatak University, Dharwad, India; *Corresponding Author: nmurthy60@yahoo.co.in
}

Received 21 April 2013; revised 22 May 2013; accepted 15 June 2013

Copyright (C) 2013 Sunita Premnath Koli, Hosakatte Niranjana Murthy. This is an open access article distributed under the Creative Commons Attribution License, which permits unrestricted use, distribution, and reproduction in any medium, provided the original work is properly cited.

\section{ABSTRACT}

A collection of melon (Cucumis melo L.) from Kerala state, Southern India, consisting of thirty three accessions was evaluated for 22 quantitative and 14 qualitative characteristics to estimate the phenotypic diversity. The collection showed appreciable phenotypic diversity in fruit related traits. Principal component analysis (PCA) was performed to determine the relationships among the populations. The analysis revealed that the variations in stem hair length, number of nodes per plant on 60th day, fruit shape, fruit length, fruit weight, fruit colour at ripening, fruit rind hardness, flesh colour, flesh firmness, quality of flesh, shelf life, seed colour were the principle characters to discriminate melon accessions evaluated in the present study. When the 33 populations were plotted on the first two principal components, accounting for $49.97 \%$ of the total variation, three clusters were identified, accounting for $\mathbf{3 6}$ morphological attributes used in the study. The greater part of diversity was accounted for fruit diameter, fruit weight, fruit length and width, fruit cavity length and diameter, seed length and colour. Flesh area of fruit, flesh thickness, leaf size, seed weight, seed index did not account for variation in the first six principal components of the melon collection. Scatter diagram segregated the acidulus and momordica into different clusters. This evaluation of fruit trait variability can assist geneticists and breeders to identify populations with desirable characteristics for inclusion in various breeding programmes.

Keywords: Cucumis melo; Genetic Diversity; Phenotypic Traits; Principle Component Analysis

\section{INTRODUCTION}

Cucumis melo L. $(2 \mathrm{n}=2 \mathrm{x}=24)$ is an economically important horticultural crop belonging to the family $\mathrm{Cu}-$ curbitaceae. A great morphological variation exists in fruit characteristics such as size, shape, colour, texture, taste and composition. Therefore, C. melo is considered as the most diverse species of the genus Cucumis [1-3]. The cultivated varieties include sweet "dessert" melons as well as non-sweet forms that are consumed raw, pickled or cooked. Such a variation provides breeders with a rich genetic resource and thus there is an increased interest in understanding their genetic diversity.

The melon germplasm of the humid tropics of Southern India has been collected and assessed by Fergany et al. [4]. They reported that the collected populations belong to two groups: C. melo var. acidulus Naudin and $C$. melo var. momordica (Roxb.) Duthie et Fuller. They also recommended that additional collections of melon genetic resources should be made from Southern India as this could lead to the discovery of genetic diversity not present in the existing world collections of melon.

Poor keeping quality of some melon varieties which produce climacteric fruits limits their wide commercial acceptance and thus long shelf life has become an important character in modern cultivars of melon. Variation exists among C. melo varieties [5-8] and studies were carried out in few varieties including inodorus, reticulatus, makuwa, sacharinus, cantalupensis, acidulus and momordica [8-14]. Hence, the main objectives of present study were to evaluate the diversity among melon accessions collected from Kerala state, Southern India and to estimate the distribution of shelf life among these populations.

\section{MATERIALS AND METHODS}

\subsection{Plant Materials and Bio-Agronomic Traits}

The present study was carried out to assess the pheno- 
typic diversity among thirty three landraces of C. melo collected in the Kerala state, Southern India (Table 1).

The landraces were evaluated in field trials using a randomized complete-block design in triplicates during December 2012 to March 2013. Each plot consisted of 1 row, $7.5 \mathrm{~m}$ long, spaced $2 \mathrm{~m}$ apart, with $1.5 \mathrm{~m}$ spacing between plants within the row. All characters (quantita- tive and qualitative characters) were measured in the field and at the normal harvest time for the estimation of phenotypic diversity. The characters selected for the analysis were pertaining mainly to $C$. melo breeding aims and were recorded for all genotypes in triplicates $[1,15,16]$. The fruit characters studied at maturity included length, diameter, shape, colour, skin and flesh

Table 1. Details of melon accessions used in the present study.

\begin{tabular}{|c|c|c|c|c|c|}
\hline $\mathrm{CmKc}$ & Collection Area & Disrict & Fruit type & Shelf life & Cluster \\
\hline 1 & Pilicode & Kasargode & Acidulus & Very good & I \\
\hline 2 & Pilicode & Kasargode & Acidulus & Very good & I \\
\hline 3 & Pilicode & Kasargode & Acidulus & Very good & I \\
\hline 4 & Pilicode & Kasargode & Acidulus & Very good & I \\
\hline 5 & Vylanthur & Thrissur & Momordica & Poor & III \\
\hline 6 & Vylanthur & Thrissur & Acidulus & Very good & I \\
\hline 7 & Kanhangad & Kasargode & Acidulus & Very good & I \\
\hline 8 & Kanhangad & Kasargode & Acidulus & Very good & I \\
\hline 9 & Kanhangad & Kasargode & Acidulus & Very good & Unclustered accession \\
\hline 10 & Nidumbal & Thrissur & Acidulus & Very good & I \\
\hline 11 & Amallor & Thrissur & Acidulus & Very good & I \\
\hline 12 & Amallor & Thrissur & Acidulus & Very good & I \\
\hline 13 & Kakkanad & Ernakulam & Momordica & Poor & III \\
\hline 14 & Mattumal & Palakkad & Acidulus & Very good & I \\
\hline 15 & Mattumal & Palakkad & Acidulus & Very good & I \\
\hline 16 & Alathur & Palakkad & Acidulus & Very good & I \\
\hline 17 & Chevayur & Kozhikode & Acidulus & Very good & I \\
\hline 18 & Kottapadi & Malappuram & Acidulus & Very good & I \\
\hline 19 & Changuvatti & Malappuram & Acidulus & Very good & I \\
\hline 20 & Ettumunoor & Kottayam & Acidulus & Very good & I \\
\hline 21 & Kamallur & Allapuzha & Acidulus & Very good & I \\
\hline 22 & Pathanamthitta & Patanamthitta & Acidulus & Very good & I \\
\hline 23 & Konni & Kollam & Momordica & Poor & II \\
\hline 24 & Thiruvananthapuram & Thiruvananthapuram & Momordica & Poor & II \\
\hline 25 & Thiruvananthapuram & Thiruvananthapuram & Momordica & Poor & II \\
\hline 26 & Edacheri & Wayanad & Acidulus & Very good & I \\
\hline 27 & Edacheri & Wayanad & Acidulus & Very good & I \\
\hline 28 & Dharmadum & Kannur & Acidulus & Very good & I \\
\hline 29 & Peravoor & Kannur & Acidulus & Very good & I \\
\hline 30 & Kasargode & Kasargode & Acidulus & Very good & I \\
\hline 31 & Pandalam & Patanamthitta & Acidulus & Very good & I \\
\hline 32 & Kottarkara & Kollam & Acidulus & Very good & I \\
\hline 33 & Thrissur & Thrissur & Momordica & Poor & III \\
\hline
\end{tabular}


thickness. Traits of fruit size and shape, such as flesh thickness, fruit length and width, placenta length were measured using the drawing ruler. Cotton blue in lacto phenol stain was used for the analysis of pollen viability.
Finally, with an aim to compare together qualitative and quantitative data, a numerical transformation was applied to traits such as flesh and rind color (Table 2). A numerical value, ranging from 1 to $\mathrm{k}$ ( $\mathrm{k}$ equal to number of

Table 2. Morphological characters measured in Cucumis melo collection.

\begin{tabular}{|c|c|c|}
\hline Character Number & Character code & Character and descriptive values \\
\hline 1 & V1 & Vine length at 60 th day in $\mathrm{cm}$ \\
\hline 2 & $\mathrm{Sh}$ & Stem hair: 1 (Soft), 2 (Intermediate), 3 (Hard) \\
\hline 3 & $\mathrm{Nb}$ & Number of branches per plant at 60th day \\
\hline 4 & $\mathrm{Nn}$ & Number of nodes per plant at 60 th day \\
\hline 5 & $\mathrm{Ll}$ & Leaf length in $\mathrm{cm}$ \\
\hline 6 & Lw & Leaf width in $\mathrm{cm}$ \\
\hline 7 & $\mathrm{Lb}$ & Leaf blade; 1 (Entire), 2 (Light lobed), 3 (Intermediate lobed) \\
\hline 8 & $\mathrm{Tl}$ & Tendril length in $\mathrm{cm}$ \\
\hline 9 & $\mathrm{Pv}$ & Pollen viability in $\%$ \\
\hline 10 & $\mathrm{Fp}$ & Fruits per plant \\
\hline 12 & $\mathrm{~F} 1$ & Fruit length in $\mathrm{cm}$ \\
\hline 13 & Fw & Fruit width in $\mathrm{cm}$ \\
\hline 14 & $\mathrm{Fd}$ & Fruit diameter in $\mathrm{cm}$ \\
\hline 15 & Fwt & Fruit weight in $\mathrm{cm}$ \\
\hline 16 & Fcr & $\begin{array}{c}\text { Fruit colour at ripening: } 1 \text { (white to green), } 2 \text { (white to orange), } 3 \text { (light green to yellow), } 4 \text { (yellow to orange), } \\
5 \text { (light green to orange) }\end{array}$ \\
\hline 17 & Frc & Fruit rind colouration: 1 (monocloured), 2 (bicoloured with longitudinal strips from base to apex) \\
\hline 18 & Frs & Fruit rind surface: 1 (smooth), 2 (cracked) \\
\hline 19 & Frp & Fruit rind pattern: 1 (plane), 2 (strips), 3 (dotted) \\
\hline 20 & Frh & Fruit rind hardness: 1(soft), 2 (intermediate), 3 (hard) \\
\hline 22 & Fth & Flesh thickness in $\mathrm{cm}$ \\
\hline 23 & Flc & Flesh colour: 1(white), 2 (light orange), 3 (green), 4 (light orange), 5 (greenish orange), 6 (orange) \\
\hline 24 & Ff & Flesh firmness: 1 (crispy), 2 (intermediate), 3 (grainy) \\
\hline 25 & Qf & Quality of flesh: 1 (crispy), 2 (intermediate), 3 (soft) \\
\hline 26 & FAF & $\begin{array}{c}\text { Flesh area of fruit in } \%:(a+b)^{2}-\left(a^{\prime}+b^{\prime}\right) \times 100 /(a+b)^{2} \\
a=\text { length of whole fruit, } a^{\prime}=\text { length of fruit cavity } \\
b=\text { diameter of whole fruit, } b^{\prime}=\text { diameter of fruit cavity }\end{array}$ \\
\hline 27 & $\mathrm{Cl}$ & Cavity length in $\mathrm{cm}$ \\
\hline 28 & $\mathrm{Cd}$ & Cavity diameter in $\mathrm{cm}$ \\
\hline 29 & Shl & Shelf life: 1 , poor ( 1 - 2 months); 2 ,intermediate ( 3 months); 3 , good (4 - 5 months); 4 , very good (6 months) \\
\hline 30 & Spf & Seeds per fruit \\
\hline 31 & $\mathrm{Sc}$ & Seed colour: 1(white), 2 (cream), 3 (light brown) \\
\hline 32 & $\mathrm{~S} 1$ & Seed length in $\mathrm{cm}$ \\
\hline 33 & Sw & Seed width in $\mathrm{cm}$ \\
\hline 34 & $\mathrm{Si}$ & Seed index \\
\hline 35 & Swt & Seed weight in grams \\
\hline 36 & Gd & Growth duration: 1 (more than 120 days), 2 (90 to 120 days), 3 (less than 90 days) \\
\hline
\end{tabular}


classes), was assigned to each phenotrait, to indicate different degrees of expression. For seed characters, 10 measurements were averaged for each plant.

\subsection{Statistical Analysis}

All the original data were standardized to eliminate the difference in the variance of each character. Principal component analysis (PCA) was performed to generate a cluster diagram. Eigen values and contribution percentage of each principal component axis were calculated using the correlation matrix among thirty six characters for thirty three accessions [17]. All computations were performed using the unscrambler 10 software (CAMO Software India Pvt. Ltd., Bangalore, India) and SPSS 17.0 for MS Windows (SPSS Inc).

\section{RESULTS AND DISCUSSION}

Thirty three accessions of melons collected from Kerala state, Southern India were evaluated to estimate the genetic diversity among the melon populations. Thirty six selected qualitative and quantitative characters were assessed in the uniform field trials (Table 2). All the melon accessions used in the analysis were monoecious and substantial genetic diversity was observed. These accessions showed a large genetic variability with respect to fruit shape and size. Principal component analysis was used to assess the variability in melon accessions. The percentage of variation explained by the first six components was 35.07, 14.90, 9.10, 6.57, 5.79 and 5.33 respectively, and the principle characters with higher Eigen vectors that delineated the accessions into separate groups in the first six components are represented in the Table 3. The variations in stem hair length, number of nodes per plant on 60th day, fruit shape, fruit length, fruit weight, fruit colour at ripening, fruit rind hardness, flesh colour, flesh firmness, quality of flesh, shelf life, seed colour were the important characters for the formation of different clusters. Figure 1 depicts the formation of three clusters with one un-clustered melon landrace. By these

Table 3. Contribution percentage and major characters associated with the first principle components of 33 melon accessions and their Eigen vector.

\begin{tabular}{|c|c|c|c|c|c|c|c|}
\hline \multicolumn{3}{|c|}{ Principle component } & 1 & 3 & 4 & 5 & 6 \\
\hline \multicolumn{3}{|c|}{ Explained proportion of variation (\%) } & 35.07 & 14.90 & 6.57 & 5.79 & 5.33 \\
\hline \multicolumn{3}{|c|}{ Cumulative proportion of variation (\%) } & 35.07 & 49.97 & 65.64 & 71.43 & 76.76 \\
\hline \multicolumn{8}{|c|}{ Eigen vector } \\
\hline $\mathrm{V} 1$ & 0.1941308 & 0.3854465 & -0.6465489 & 0.1627286 & 0.09019072 & & -0.0867000 \\
\hline $\mathrm{Sh}$ & -0.9686255 & 0.1757309 & 0.03016858 & 0.03681153 & 0.1206224 & & 0.08627229 \\
\hline $\mathrm{Nb}$ & 0.2316808 & 0.2728379 & 0.2949748 & 0.2125249 & 0.3891021 & & -0.6061266 \\
\hline $\mathrm{Nn}$ & 0.01770082 & 0.2052537 & 0.3517672 & -0.07458628 & 0.3291233 & & -0.7096581 \\
\hline $\mathrm{L} 1$ & -0.1688125 & -0.2735105 & -0.5529157 & 0.4031258 & 0.232549 & & -0.1618984 \\
\hline $\mathrm{Lw}$ & 0.1007167 & -0.3312536 & -0.09961649 & -0.005759506 & 0.4643296 & & -0.1944669 \\
\hline $\mathrm{Tl}$ & 0.2230351 & 0.28338 & -0.4395817 & 0.03696718 & 0.5926297 & & -0.0230449 \\
\hline $\mathrm{Pv}$ & 0.2668421 & 0.2517732 & 0.0665976 & -0.1027278 & 0.1960052 & & 0.1466913 \\
\hline $\mathrm{Fp}$ & -0.3765168 & -0.3617526 & 0.3858287 & 0.394814 & 0.03369923 & & 0.0822719 \\
\hline Fsh & 0.5391971 & -0.0540669 & -0.4160905 & -0.1364919 & 0.3445447 & & 0.09465964 \\
\hline $\mathrm{F} 1$ & 0.7227173 & 0.308144 & 0.3233948 & -0.06559674 & 0.170721 & & 0.3318942 \\
\hline $\mathrm{Fw}$ & 0.1537337 & 0.7595731 & 0.2415445 & -0.2481305 & 0.01015097 & & -0.0214247 \\
\hline $\mathrm{Fd}$ & 0.04803415 & 0.8598647 & -0.1049251 & -0.1545179 & 0.07193942 & & 0.06991526 \\
\hline Fwt & 0.2628347 & 0.7860266 & 0.1906711 & -0.11744 & -0.00634643 & & -0.0315025 \\
\hline Fcr & -0.9686255 & 0.1757309 & 0.03016858 & 0.03681153 & 0.1206224 & & 0.08627229 \\
\hline Frh & -0.9686255 & 0.1757309 & 0.03016858 & 0.03681153 & 0.1206224 & & 0.08627229 \\
\hline Fth & 0.05059452 & 0.1882358 & -0.7923409 & -0.06250334 & -0.04250038 & & 0.08531409 \\
\hline Flc & 0.9686255 & -0.1757309 & -0.03016858 & -0.03681153 & -0.1206224 & & -0.0862722 \\
\hline $\mathrm{Ff}$ & 0.9686255 & -0.1757309 & -0.03016858 & -0.03681153 & -0.1206224 & & -0.0862722 \\
\hline
\end{tabular}




\begin{tabular}{|c|c|c|c|c|c|c|}
\hline \multicolumn{7}{|c|}{ Continued } \\
\hline Qf & 0.9686255 & -0.1757309 & -0.03016858 & -0.03681153 & -0.1206224 & -0.0862722 \\
\hline FAF & -0.3263147 & 0.1537797 & -0.1432286 & -0.5821441 & -0.07895434 & -0.210587 \\
\hline $\mathrm{Cl}$ & 0.6670699 & 0.2680832 & 0.4493805 & 0.02985854 & 0.03566362 & 0.2570127 \\
\hline $\mathrm{Cd}$ & 0.2118728 & 0.7323623 & -0.08459914 & -0.01454906 & 0.1111293 & 0.3136823 \\
\hline Shl & -0.9686255 & 0.1757309 & 0.03016858 & 0.03681153 & 0.1206224 & 0.08627229 \\
\hline Spf & 0.1499597 & 0.384278 & -0.3905573 & 0.5643572 & -0.3008645 & 0.04569659 \\
\hline $\mathrm{Sc}$ & 0.9051051 & -0.1046764 & -0.08269551 & 0.0444922 & -0.02368167 & -0.0326795 \\
\hline $\mathrm{S} 1$ & 0.5496318 & 0.5316715 & 0.1352246 & 0.4556467 & 0.0162517 & 0.02770174 \\
\hline $\mathrm{Sw}$ & -0.0274061 & 0.6619 & -0.00583967 & 0.3822937 & -0.4315375 & -0.315695 \\
\hline $\mathrm{Si}$ & 0.5580416 & -0.2469485 & 0.1362616 & -0.000254083 & 0.5087599 & 0.3873413 \\
\hline Swt & 0.1028545 & -0.09773537 & 0.2895683 & 0.6930479 & 0.1978223 & 0.1617651 \\
\hline $\mathrm{Gd}$ & 0.9686255 & -0.1757309 & -0.03016858 & -0.03681153 & -0.1206224 & -0.0862722 \\
\hline
\end{tabular}

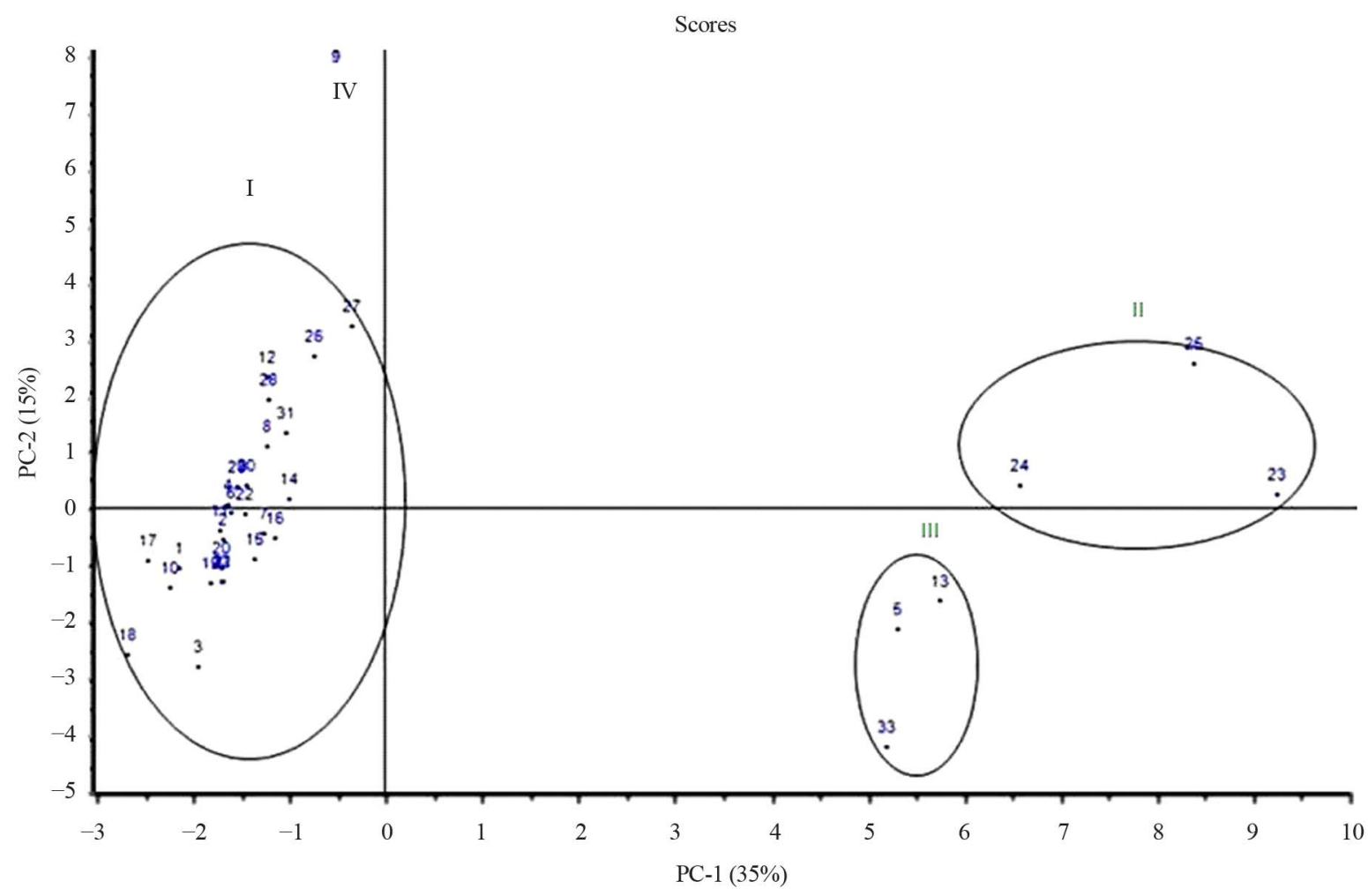

Figure 1. Cluster diagram constructed on the basis of the first two principle component axes, which contain $50 \%$ of the total variation.

components, accessions showing large variation in vine length $(101 \mathrm{~cm}$ to $220 \mathrm{~cm})$, number of branches on 60th day (12 to 20), number of nodes on 60th day (25 to 43), tendril length $(24 \mathrm{~cm}$ to $51 \mathrm{~cm})$, fruit shape (ovate to oblate), fruit length $(15 \mathrm{~cm}$ to $43 \mathrm{~cm})$, fruit width $(7 \mathrm{~cm}$ to $12 \mathrm{~cm})$, stem hair length, fruit colour at ripening, seed colour, larger fruit diameter with medium growth duration (within 120 days) were grouped into a larger cluster in the left and the collections in this cluster were mainly acidulus (Figure 1). Accessions with longer vine length and leaf length, larger fruit length, heavy fruit weight, light green to yellow fruit colour, soft rind, light orange flesh colour, grainy and intermediate flesh, poor shelf life (1 - 2 months), light brown seeds, short growth duration (within 90 days) were on the right of the scatter diagram, and these accessions on the right of the scatter diagram were momordica (Figure 1). Cluster 3 included landraces which showed almost similar characters as that of 
the landraces grouped in cluster 2 with heavy fruit weight, light green to yellow fruit colour, soft rind, grainy and intermediate flesh, light orange flesh colour, moderate fruit length, poor shelf life (1 - 2 months), light brown seeds, short growth duration (within 90 days). These accessions on the right of the scatter diagram were momordica (Figure 1). The unclustered landrace CmKc-9 had long vein length, higher number of nodes on 60th day, smaller leaf size, higher fruit width, heavy fruit weight, medium growth duration (within 120 days). This landrace included the acidulus. The range for primary branches per plant was from twelve to twenty in acidulus which was almost similar to the branch profile of the momordica. The minimum and maximum vein length and number of nodes per plant was almost same in both the varieties. A detailed description of the melon fruits used in the study is given in Table $\mathbf{4}$ and mean trait values of each cluster for their quantitative characters are mentioned in Table 5. The range of variability of phenoltypic characters in terms of minimum

Table 4. Fruit traits of melon accessions.

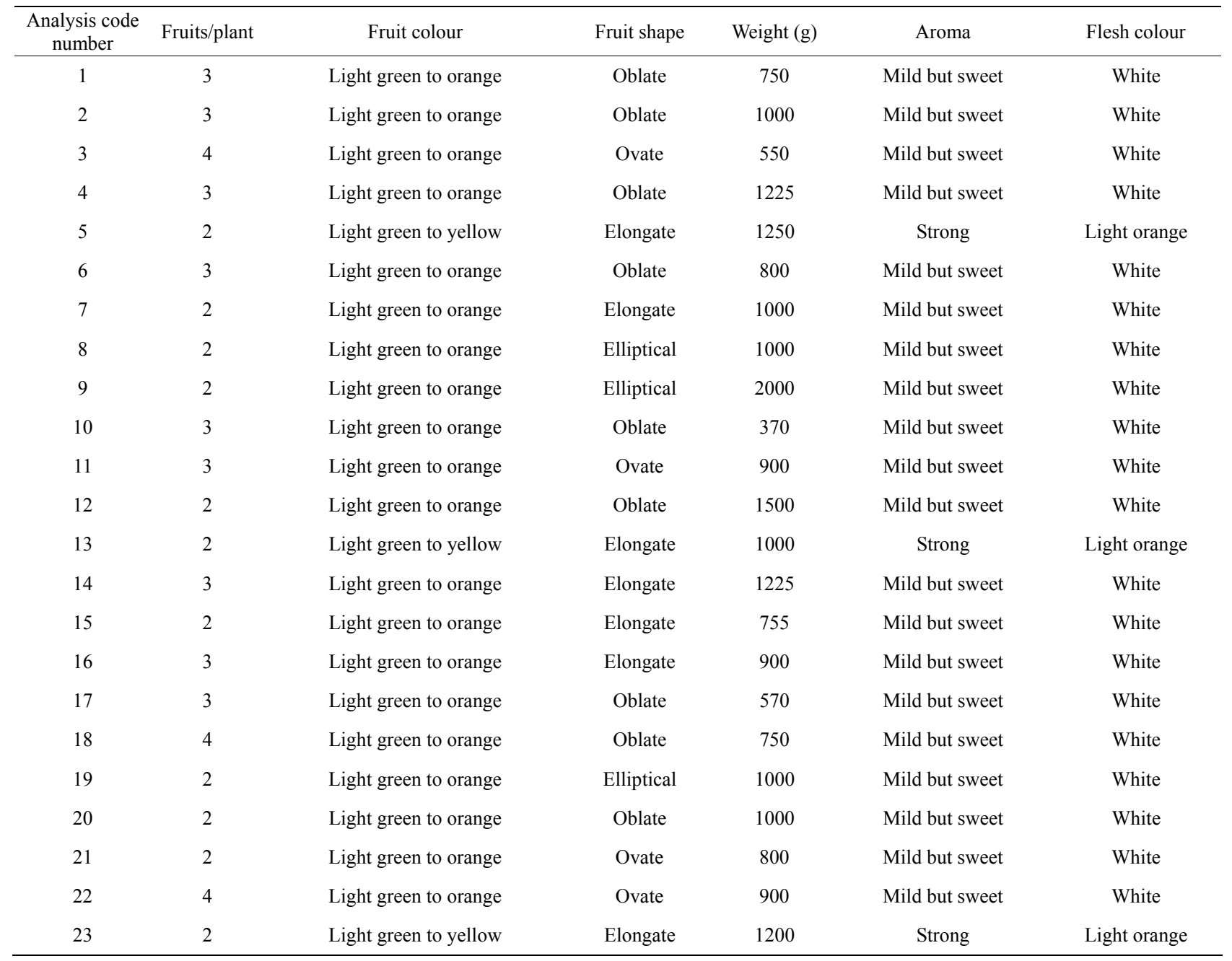

Table 5. Mean trait values used in Cucumis melo cluster identification.

\begin{tabular}{cccc}
\hline Traits & Cluster I & Cluster II & Cluster III \\
\hline $\mathrm{Vl}$ & $153.0 \pm 41.46$ & $44.75 \pm 506.4$ & $147.6 \pm 34.195$ \\
$\mathrm{Sh}$ & $3.00 \pm 0.00$ & $1.000 \pm 0.000$ & $1.000 \pm 0.000$ \\
$\mathrm{Nb}$ & $16.50 \pm 2.68$ & $313.7 \pm 590.84$ & 3 \\
$\mathrm{Nn}$ & $33.65 \pm 5.19$ & $39.16 \pm 8.207$ & $32.66 \pm 5.68$ \\
$\mathrm{Ll}$ & $11.73 \pm 2.28$ & $26.20 \pm 18.51$ & $11.66 \pm 2.19$ \\
\hline
\end{tabular}


Continued

\begin{tabular}{|c|c|c|c|c|}
\hline $\mathrm{Lw}$ & $17.84 \pm 2.51$ & $30.31 \pm 14.38$ & $18.20 \pm 1.00$ & 13.9 \\
\hline $\mathrm{Tl}$ & $38.73 \pm 8.21$ & $42.00 \pm 10.39$ & $40.33 \pm 9.60$ & 49 \\
\hline $\mathrm{Pv}$ & $96.69 \pm 7.14$ & $100.0 \pm 0.000$ & $100.0 \pm 0.00$ & 100 \\
\hline $\mathrm{Fp}$ & $2.576 \pm 0.757$ & $2.000 \pm 0.000$ & $2.000 \pm 0.000$ & 2 \\
\hline Fsh & $4.961 \pm 1.611$ & $7.000 \pm 0.000$ & $7.000 \pm 0.000$ & 4 \\
\hline $\mathrm{Fl}$ & $21.80 \pm 5.982$ & $52.00 \pm 7.810$ & $23.16 \pm 8.51$ & 23 \\
\hline $\mathrm{Fw}$ & $8.80 \pm 1.288$ & $10.73 \pm 1.553$ & $7.30 \pm 2.13$ & 12 \\
\hline $\mathrm{Fd}$ & $30.68 \pm 5.712$ & $34.20 \pm 2.662$ & $25.26 \pm 3.65$ & 43.3 \\
\hline Fwt & $814.6 \pm 372.421$ & $1335.0 \pm 212.5$ & $483.3 \pm 448.14$ & 2.000 \\
\hline Fcr & $5.000 \pm 0.000$ & $3.000 \pm 0.000$ & $3.000 \pm 0.000$ & 5 \\
\hline Frs & $2.000 \pm 0.000$ & $4.000 \pm 0.000$ & $3.000 \pm 0.000$ & 1 \\
\hline Frp & $2.192 \pm 0.401$ & $2.000 \pm 0.000$ & $1.33 \pm 0.57$ & 2 \\
\hline Frh & $2.000 \pm 0.000$ & $1.000 \pm 0.000$ & $1.000 \pm 0.000$ & 2 \\
\hline Fth & $2.242 \pm 0.441$ & $2.300 \pm 0.346$ & $2.26 \pm 0.40$ & 2.5 \\
\hline Flc & $1.000 \pm 0.000$ & $2.000 \pm 0.000$ & $2.000 \pm 0.000$ & 1 \\
\hline $\mathrm{Ff}$ & $1.000 \pm 0.000$ & $3.000 \pm 0.000$ & $3.000 \pm 0.000$ & 1 \\
\hline Qf & $1.000 \pm 0.000$ & $2.000 \pm 0.000$ & $2.000 \pm 0.000$ & 1 \\
\hline FAF & $98.1 \pm 0.988$ & $96.14 \pm 5.21$ & $97.75 \pm 0.88$ & 96.55 \\
\hline $\mathrm{Cl}$ & $19.65 \pm 5.698$ & $43.43 \pm 14.165$ & $22.86 \pm 10.41$ & 25 \\
\hline $\mathrm{Cd}$ & $16.64 \pm 2.319$ & $492.0 \pm 79.170$ & $14.60 \pm 0.87$ & 22.6 \\
\hline Shl & $4.000 \pm 0.000$ & $1.000 \pm 0.000$ & $1.000 \pm 0.000$ & 4 \\
\hline Spf & $446.6 \pm 123.7$ & $492.0 \pm 79.170$ & $503.0 \pm 136.96$ & 848 \\
\hline $\mathrm{Sc}$ & $2.000 \pm 0.000$ & $3.000 \pm 0.000$ & $2.66 \pm 0.57$ & 2 \\
\hline $\mathrm{Sl}$ & $9.000 \pm 0.000$ & $0.966 \pm 0.057$ & $9.00 \pm 0.00$ & 1 \\
\hline $\mathrm{Sw}$ & $4.000 \pm 0.000$ & $4.000 \pm 0.000$ & $4.000 \pm 0.000$ & 0.5 \\
\hline $\mathrm{Si}$ & $2.250 \pm 0.000$ & $2.416 \pm 0.144$ & $2.250 \pm 0.000$ & 2 \\
\hline Swt & $1151.1 \pm 182.8$ & $1224.0 \pm 303.464$ & $1142.6 \pm 160.31$ & 1202 \\
\hline $\mathrm{Gd}$ & $2.000 \pm 0.000$ & $3.000 \pm 0.000$ & $3.000 \pm 0.000$ & 2 \\
\hline
\end{tabular}

and maximum and mean values are presented in Table 6. Morphological variation was most apparent in fruit length which varied from $15 \mathrm{~cm}$ to $43 \mathrm{~cm}$ per fruit in acidulus whereas in momordica it was from $15 \mathrm{~cm}$ to 57 $\mathrm{cm}$ per fruit. Fruit colour was also quite similar rangingfrom light green to yellow or orange (Figure 2). The fruit colour of the accessions, CmKc-5, CmKc-13, CmKc-23, CmKc-24, CmKc-25 and CmKc-33 was mainly light green to yellow which were grouped in cluster 2 and 3 which included mainly momordica (Figure 3). The fruits of acidulus were generally ovate to oblate in shape except in $\mathrm{CmKc}-8$, but those of momordica were elongated except in $\mathrm{CmKc}-3$ which was ovate. The average fruit weight of the collections varied greatly. The fruit weight varied from $420 \mathrm{~g}$ to $1250 \mathrm{~g}$ per fruit in acidulus, in momordica it varied from $200 \mathrm{~g}$ to $1580 \mathrm{~g}$ per fruit with CmKc-9 gaining the maximum fruit weight of $2000 \mathrm{~g}$ per fruit. The flesh of the fruits was generally white to light orange in color and crispy to grainy in nature. The flesh colour was white in acidulus and it was light orange in momordica (Table 4). Most of the momordica landraces had a strong odour at maturity except for $\mathrm{CmKc}-3$ which had a mild and sweet odour. The fruits of acidulus were non climacteric, very firm and did not crack at maturity (Figure 2) and these fruits are used for cooking purpose in Kerala. The fruits of momordica were, climacteric, soft and cracked at maturity (Figures 3(e)-(f)), hence had very low shelf life and these fruits are also used for 
Table 6. Variability in some quantitative characters of acidulus and momordica landraces.

\begin{tabular}{|c|c|c|c|c|c|c|}
\hline \multirow{3}{*}{ Trait } & \multicolumn{3}{|c|}{ Cucumis melo var. acidilus } & \multicolumn{3}{|c|}{ Cucumis melo var. momordica } \\
\hline & \multicolumn{3}{|c|}{ Cluster I } & \multicolumn{3}{|c|}{ Cluster II } \\
\hline & Minimum values & Maximum values & Mean $\pm \mathrm{SD}$ & Minimum values & Maximum values & Mean \pm SD \\
\hline $\mathrm{Vl}$ & 101 & 220 & $153 \pm 41.46$ & 176 & 210 & $187 \pm 19.3$ \\
\hline $\mathrm{Sh}$ & 3 & 3 & $3.00 \pm 0.00$ & 1 & 1 & $1.00 \pm 0.00$ \\
\hline $\mathrm{Nb}$ & 12 & 20 & $16.5 \pm 2.68$ & 14 & 23 & $18.3 \pm 4.50$ \\
\hline $\mathrm{Nn}$ & 25 & 43 & $33.6 \pm 5.19$ & 30 & 42 & $36.3 \pm 6.02$ \\
\hline $\mathrm{Ll}$ & 9.7 & 18.9 & $11.7 \pm 2.28$ & 10.1 & 10.8 & $10.4 \pm 0.36$ \\
\hline $\mathrm{Lw}$ & 10.7 & 20.1 & $17.8 \pm 0.49$ & 18.2 & 18.9 & $18.6 \pm 0.37$ \\
\hline $\mathrm{Tl}$ & 24 & 51 & $38.7 \pm 8.21$ & 30 & 48 & $42.0 \pm 10.3$ \\
\hline $\mathrm{Pv}$ & 75 & 100 & $96.6 \pm 7.14$ & 100 & 100 & $100.0 \pm 0.00$ \\
\hline $\mathrm{Fp}$ & 1 & 4 & $2.57 \pm 0.75$ & 2 & 2 & $2.00 \pm 0.00$ \\
\hline Fsh & 3 & 7 & $4.96 \pm 1.61$ & 7 & 7 & $7.00 \pm 0.00$ \\
\hline $\mathrm{F} 1$ & 15 & 43 & $21.8 \pm 5.98$ & 43 & 57 & $52.0 \pm 7.81$ \\
\hline $\mathrm{Fw}$ & 7 & 12 & $8.80 \pm 1.28$ & 9 & 12 & $10.7 \pm 1.55$ \\
\hline $\mathrm{Fd}$ & 17 & 40 & $30.6 \pm 5.71$ & 31 & 34 & $34.2 \pm 2.66$ \\
\hline Fwt & 370 & 1500 & $922 \pm 285.2$ & 1200 & 1580 & $1335 \pm 212$ \\
\hline Fcr & 5 & 5 & $5.00 \pm 0.00$ & 3 & 3 & $3.00 \pm 0.00$ \\
\hline Frs & 1 & 1 & $1.00 \pm 0.00$ & 4 & 4 & $4.00 \pm 0.00$ \\
\hline Frp & 2 & 3 & $2.19 \pm 0.40$ & 2 & 2 & $2.00 \pm 0.00$ \\
\hline Frh & 2 & 2 & $2.00 \pm 0.00$ & 1 & 1 & $1.00 \pm 0.00$ \\
\hline Fth & 1.4 & 2.5 & $2.62 \pm 2.06$ & 1.9 & 2.5 & $2.30 \pm 0.34$ \\
\hline Flc & 1 & 1 & $1.00 \pm 0.00$ & 2 & 2 & $2.00 \pm 0.00$ \\
\hline $\mathrm{Ff}$ & 1 & 1 & $1.00 \pm 0.00$ & 3 & 3 & $3.00 \pm 0.00$ \\
\hline Qf & 1 & 1 & $1.00 \pm 0.00$ & 2 & 2 & $2.00 \pm 0.00$ \\
\hline FAF & 95 & 99 & $98.1 \pm 0.98$ & 90 & 99 & $96.1 \pm 5.21$ \\
\hline $\mathrm{Cl}$ & 13 & 40 & $19.6 \pm 5.69$ & 31 & 59 & $43.3 \pm 14.1$ \\
\hline $\mathrm{Cd}$ & 12 & 20 & $16.6 \pm 2.31$ & 15 & 26 & $20.1 \pm 5.52$ \\
\hline Shl & 4 & 4 & $4.00 \pm 0.00$ & 1 & 1 & $1.00 \pm 0.00$ \\
\hline $\mathrm{Spf}$ & 221 & 948 & $458 \pm 153$ & 410 & 568 & $492 \pm 79.1$ \\
\hline $\mathrm{Sc}$ & 2 & 2 & $2.00 \pm 0.00$ & 3 & 3 & $3.00 \pm 0.00$ \\
\hline $\mathrm{S} 1$ & 0.9 & 0.9 & $0.90 \pm 0.00$ & 0.9 & 1 & $0.96 \pm 0.57$ \\
\hline $\mathrm{Sw}$ & 0.4 & 0.4 & $0.40 \pm 0.00$ & 0.4 & 0.4 & $0.40 \pm 0.00$ \\
\hline $\mathrm{Si}$ & 0.25 & 2.25 & $2.17 \pm 0.39$ & 2.25 & 2.50 & $2.41 \pm 0.14$ \\
\hline Swt & 100 & 158 & $1151 \pm 182$ & 1003 & 1570 & $1224 \pm 303$ \\
\hline $\mathrm{Gd}$ & 2 & 2 & $2.00 \pm 0.00$ & 3 & 3 & $3.00 \pm 0.00$ \\
\hline
\end{tabular}



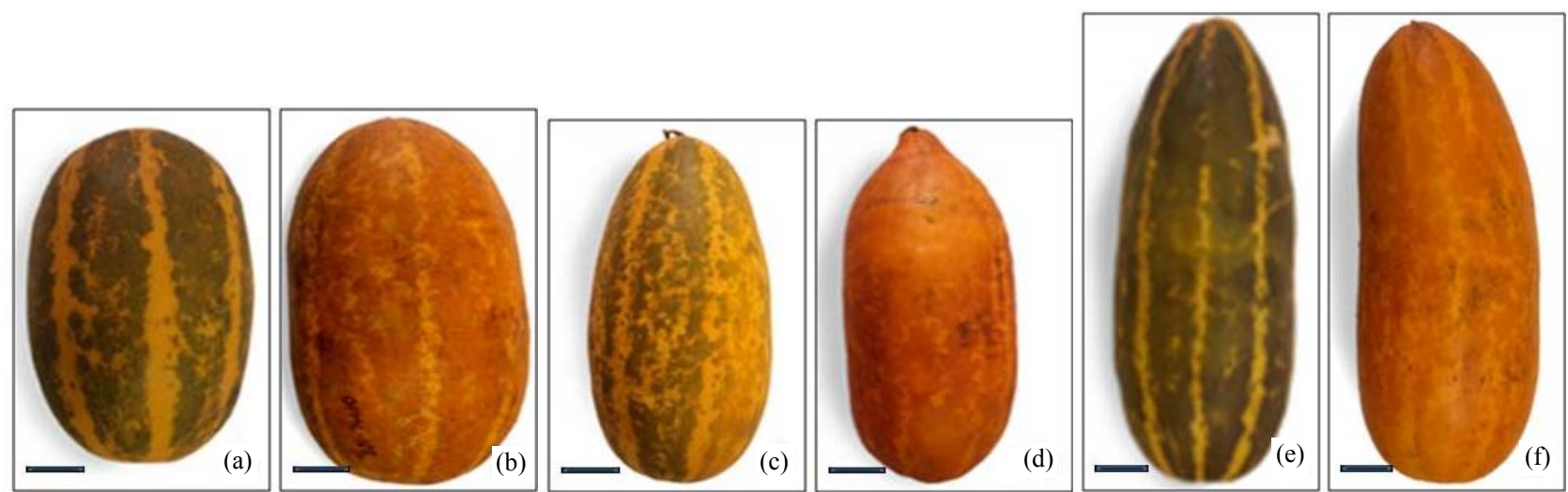

Figure 2. Variability in fruits of Cucumis melo var. acidulus landraces: (a) Tender oblate fruit of CmKc-3 landrace $(\mathrm{Bar}=2.66 \mathrm{~cm})$; (b) Ripe fruit of CmKc-3 landrace $(B a r=3.21 \mathrm{~cm})$; (c) Tender fruit of CmKc-14 landrace $($ Bar $=4.92 \mathrm{~cm})$; (d) Ripe fruit of CmKc-22 landrace $(\mathrm{Bar}=5.04 \mathrm{~cm})$; (e) Tender elongated fruit of $\mathrm{CmKc}-15$ landrace $(\mathrm{Bar}=3.5 \mathrm{~cm})$; (f) Ripe fruit of CmKc-27 landrace $(\mathrm{Bar}=3.26 \mathrm{~cm})$.
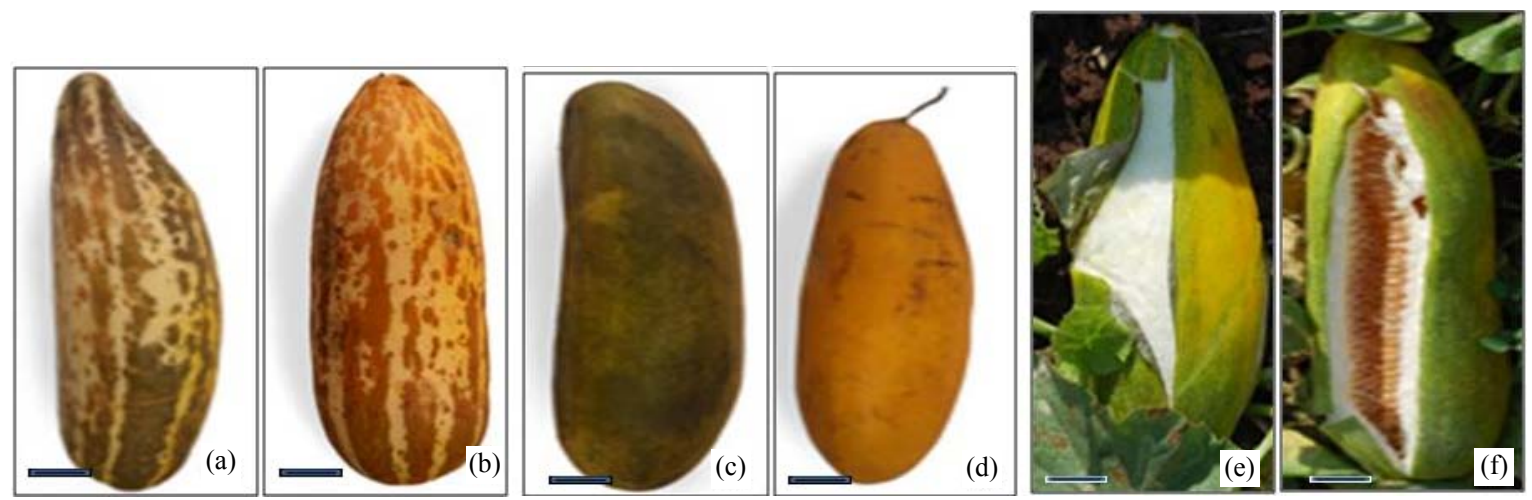

Figure 3. Variability in fruits of Cucumis melo var. momordica landraces: (a) Tender plane fruit of CmKc-5 landrace $($ Bar $=4.95 \mathrm{~cm})$; (b) Ripe fruit of CmKc-13 landrace $(\mathrm{Bar}=5.4 \mathrm{~cm}) ;(\mathrm{c})$ Tender fruit of CmKc-24 landrace $(\mathrm{Bar}=5.07$ $\mathrm{cm})$; (d) Ripe fruit of CmKc-23 landrace $(\mathrm{Bar}=5.78 \mathrm{~cm})$; (e) Peeled fruit of CmKc-25 landrace $(\mathrm{Bar}=3.17 \mathrm{~cm})$; $(\mathrm{f})$ Fruit cracking in $\mathrm{CmKc}-33$ landrace $(\mathrm{Bar}=3.4 \mathrm{~cm})$.

cooking before maturity. The seeds of acidulus and momordica were medium sized, white in colour and maximum seed length was 0.9 and $1.0 \mathrm{~cm}$ respectively. The present survey of morpho-metric analysis of Kerala landraces of melon revealed considerable variability especially with fruit characteristics. The landraces belonged to two varieties, acidulus and momordica which possessed non sweet fruits which are consumed as cooked vegetables. These observations support the views of Fergany et al. [4], Manohar and Murthy [14] that South Indian melon landraces comprises of acidulus and momordica. The data on shelf-life and its correlation with other characteristics is presented in Table 7. Fruit shape, fruit weight, flesh colour, quality of flesh, flesh firmness were highly correlated with shelf-life of melon fruits. Accessions with good shelf-life belong to acidulus variety and these accessions were characterized by fruits possessing firm skin, non-climacteric, non-juicy, crisp with white flesh. The fruits of such accession could be stored more than six months without loss of quality. As-
Table 7. Correlation coefficients between shelf life and other characters.

\begin{tabular}{cc}
\hline Character & Shelf life \\
\hline Fruit shape & 0.31087 \\
Fruit colour & 0.16896 \\
Fruit weight & 0.37343 \\
Flesh colour & 0.33142 \\
Flesh thickness & 0.18398 \\
Quality of flesh & 0.33142 \\
Flesh firmness & 0.57446 \\
Rind hardness & 0.21542 \\
100 seed weight & 0.15917 \\
Growth duration & 0.16923 \\
\hline
\end{tabular}

sessment of shelf-life among melon accessions was carried 
out in C. melo var. sacharinus (Hami-melon) [18], and selected accessions have been used for breeding programme.

\section{CONCLUSION}

It was reported that melon germplasm (acidulus and momordica) of Southern India possess resistance to $\mathrm{Cu}-$ cumber mosaic virus, Zucchini yellow mosaic virus, Powdery mildew (races 1, 2, 3 and 5), Fusarium wilt (races 1 and 2), Aphis gossypii and leafminer [4]. The landraces collected from Kerala state showed increased shelf-life. However, these land races should be assessed for disease resistance characteristics by using molecular markers. These landraces need to be analyzed for their ability to be used as bred cultivars for commercial breeding purpose.

\section{ACKNOWLEDGEMENTS}

The authors express sincere thanks to Dr. N.P.S. Dhillon and Dr. Balvir Kaur, Department of Vegetable Crops, Punjab Agricultural University, Ludhiana, India, for helpful comments on the manuscript. Authors are thankful to Department of Biotechnology (DBT-KUD-IPLS program BT/PR14555/INF/22/126/2010), University Grants Commission [Project No. F.No. 41-423/2012 (SR)], New Delhi and Department of Atomic Energy (BRNS project No. 2013/35/BRNS/20), Mumbai for financial assistance.

\section{REFERENCES}

[1] Kirkbride, J.H. (1993) Biosystematic monograph of the genus Cucumis (Cucurbitaceae). Parkway Publishers, Boone.

[2] Whitaker, T.W. and Davis, G.N. (1962) Cucurbits: Botany, cultivation, and utilization. Interscience Publishers, New York.

[3] Jeffery, C. (1980) A review of the Cucurbitaceae. Botanical Journal of the Linnean Society, 81, 223-247.

[4] Fregany, M., Balvir, K., Monforte, A.J., Pitrat, M., Rys, C., Lecoq, H., Dhillon, N.P.S. and Dhaliwal, S.S. (2011) Variation in melon (Cucumis melo) landraces adapted to the humid tropics of southern India. Genetic Resources and Crop Evolution, 58, 227-243.

[5] Kitamura, T., Kmemoto, T. and Akazawa, T. (1975) Studies on the storage of melon fruits II. Changes of respiration and ethylene production during ripening with reference to cultivars. Journal of the Japanese Society for Horticultural Sciences, 44, 197-203. doi:10.2503/jjshs.44.197

[6] Shiomi, S., Yamamoto, M., Nakamura, R. and Inaba, A. (1999) Expression of ACC oxidase genes in melon harvested at different stages of maturity. Journal of the Japa- nese Society for Horticultural Sciences, 68, 10-17. doi:10.2503/jjshs.68.10

[7] Miccolis, V. and Salveit Jr., M.E. (1991) Morphological and physiological changes during fruit growth and maturation of seven melon cultivars. Journal of American Society for Horticultural Science, 116, 1025-1029.

[8] Liu, L., Kakihara, F. and Masahiro, K. (2004) Characterization of six varieties of Cucumis melo L. based on morphological and physiological characters including shelf-life of fruit. Euphytica, 135, 305-313. doi:10.1023/B:EUPH.0000013330.66819.6f

[9] Guis, M., Botondi, R., Ben-Amor, M., Ayub, R., Bouzayen, M., Pech, J.C. and Latche, A. (1997) Ripeningassociated biochemical traits of cantaloupe Charentias melon expressing antisense ACC oxidase transgene. Journal of American Society for Horticultural Science, 122, 748-751.

[10] Ayub, R., Guis, M., Ben-Amor, M., Gillot, L., Roustan, J.P., Latche, A., Bouzyen, M. and Pech, J.P. (1996) Expression of ACC oxidase antisense gene inhibits ripening of cantloupe melon fruits. Nature Biotechnology, 14, 862866. doi:10.1038/nbt0796-862

[11] Hadfield, K.A., Rose, J.K.C. and Bennett, A.B. (1995) The respiratory climacteric is present in Charentais $(\mathrm{Cu}$ cumis melo cv. reticulates F1 Alpha) melons ripened on or off the plant. Journal of Experimental Botany, 46, 19231925. doi:10.1093/jxb/46.12.1923

[12] Lester, G. (1988) Comparison of "Honey Dew" and netted muskmelon fruit tissues in relations to storage life. HortScience, 23, 180-182.

[13] Pratt, H.K., Goeschl, J.D. and Martin, F.W. (1977) Fruit growth and development, repining and role of ethylene in the "Honey Dew" muskmelon. Journal of American Society for Horticultural Science, 102, 203-210.

[14] Manohar, S.H. and Murthy, H.N. (2012) Estimation of phenotypic divergence in a collection of Cucumis melo, including shelf-life of fruit. Scientia Horticulturae, 148, 74-82. doi:10.1016/j.scienta.2012.09.025

[15] Robinson, R.W., Munger, H.M., Whitaker, T.W. and Bohn, G. W. (1976) Genes of Cucurbitaceae. Horticultural Science, 11, 554-568.

[16] Ramaswamy, B., Seshadri, V.S. and Sharma, J.C. (1977) Inheritance of some fruit characters of muskmelon. Scientia Horticulturae, 6, 107-120. doi:10.1016/0304-4238(77)90027-9

[17] Jeffers, J.N.R. (1967) Two case studies in the application principal component analysis. Applied Statistics, 16, 225236. doi: $10.2307 / 2985919$

[18] Li, X.X., Kaldhara, F. and Kato, M. (1994) Character of Chinese Hami melons cultivated under vinlayl house condition. Memoirs of the College of AgricultureEhime University, 39, 180. 


\section{APPENDIX}

Abbreviations: CmKc-Cucumis melo Kerala collection, PCA-Principle Component Analysis 